International Journal of Social Science And Human Research

ISSN(print): 2644-0679, ISSN(online): 2644-0695

Volume 05 Issue 02 February 2022

DOI: 10.47191/ijsshr/v5-i2-42, Impact factor-5.586

Page No: 697-701

\title{
The Murders in the Rue Morgue by Edgar Allan-Poe: Content Analysis in the Context of Archetypal Approach
}

\author{
May R. Estrera, MAT ${ }^{\mathbf{1}}$, Gilda E. Deguma, Ed.D. ${ }^{2}$, Aurelia R. Estrera, MA ${ }^{3}$ \\ ${ }^{1}$ Teacher III, Estancia National High School, Estancia 5017, Iloilo \\ ${ }^{2}$ Associate Professor V, Northern Iloilo Polytechnic State College, Estancia 5017, Iloilo \\ ${ }^{3}$ Associate Professor I, Northern Iloilo Polytechnic State College, Estancia 5017, Iloilo
}

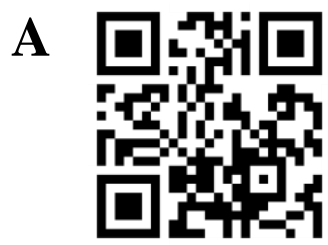

ABSTRACT: This qualitative descriptive research aims to analyse the story The Murders in the Rue Morgue by Edgar Allan Poe using the Archetypal Theory in terms of Situation Archetype, Setting Archetype, Symbolic, and Character Archetypes. A researchers made questionnaire validated by three jurors was used to analyse the story. Under the Situation Archetype, it was revealed that each character in the story has passed different passages that made their roles in the story. With this, the story was able to become more interesting and appealing to the readers. Setting archetype presented the adventures and risks in the lives of the characters as they search for truth behind the mystery murder. It revealed the significance of each setting in the wholeness of the story and unveiled the fact that the story is about alliance and adventure. The Symbolic Archetype presented the substance of the story when given deeper understanding. The symbols present in the story contain meanings that answer why and how things were given important functions. Lastly, the Character Archetype presented the real identity of the characters especially when put under situations they cannot control. It projected composure, violence, and fear. It presented the ways of men when they have the world with them and when everything is against them.

KEYWORDS: The Murders in the Rue Morgue, Edgar Allan Poe, content analysis, archetypes,

\section{INTRODUCTION}

Literature in its simplest term deals with the ideas, thoughts of man's aspirations, dreams, loves, grief, and experiences written in imaginative and beautiful language (Abing, 2007). It means not only what is written but what is voiced, what is expressed, in whatever form - in which comic strips, speeches, photographs, movies, and music all huddle beneath the literary umbrella (Krystal, 2014). The researchers chose to conduct this study because understanding this literary piece by Edgar Allan Poe would provide more knowledge about the genre and the approach used in the story. Content analysis also uses critical thinking skills.

The Murders in the Rue Morgue by Edgar Allan Poe, known as the first detective short story, was found by the researchers interesting and worthy to be studied and is hoped to boost the interest of the readers to analyze a story, as well as stir the aesthetic appreciation on literature. The deeper a person tries to understand what he or she reads, the more values and realizations he or she gets. This study aimed to analyse the story The Murders in the Rue Morgue by Edgar Allan-Poe using the four branches of Archetypal Theory such as: A. Situation Archetype, B. Setting Archetype, C. Symbolic Archetype, and D. Characters Archetype. The paradigm of the study is hereby presented:

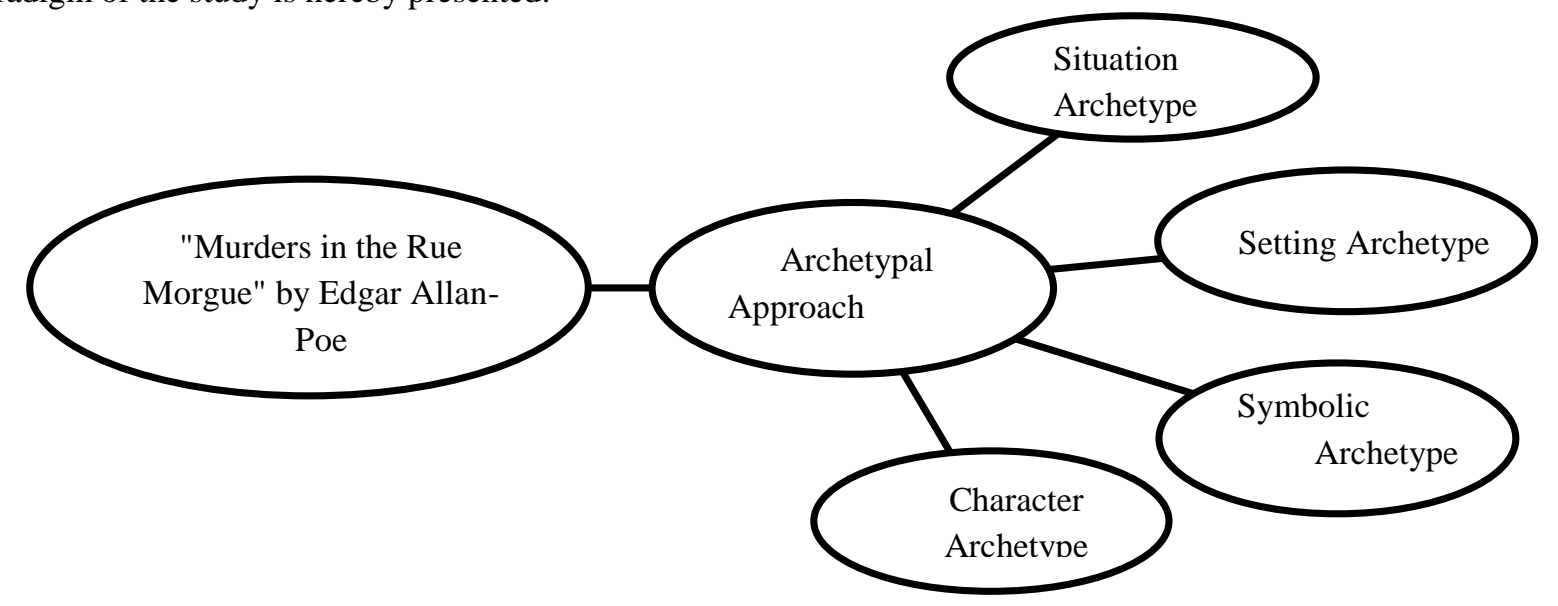




\section{The Murders in the Rue Morgue by Edgar Allan-Poe: A Content Analysis in the Context of Archetypal Approach}

\section{METHODOLOGY \\ Participants}

The participants in the study were the researchers, and the three corroborators who were Master's Degree holders and experts in the field of literature. These three corroborators substantiated and confirmed the claims of the researchers, being the first to analyse the literary piece.

\section{Research Design}

This study is a descriptive-qualitative research, specifically content analysis on the following: Character, Setting, Situation and Symbolic Archetypes. Descriptive research is one in which information is collected without changing the environment.it is used to obtain information concerning the current status of the phenomena to describe "what exists" with respect to variables or conditions in a situation (Posinasetti, 2014). Content analysis is a research method for studying communication artifacts.

\section{Materials and Instrumentation}

A researchers-made questionnaire was used as a guide in the analysis of the story.

\section{Data Analysis Procedure}

The researchers focused on the analysis of a pioneer detective fiction story. The data were submitted to the three corroborators upon the recommendation of the research panel to verify and substantiate their claims for the analysis.

\section{RESULTS}

Edgar Allan Poe's The Murders in the Rue Morgue contains archetypes that travelled into the unconscious minds of the readers. Aside from the fact that it is one of the pioneer detective stories, it depicts different personalities of characters when faced into uncontrolled situations. The analysis of the story in the context of the Archetypal Approach is hereby presented.

\section{A. SITUATION ARCHETYPE}

The Quest. One of the most often traced archetypal patterns is that of the quest (or search) by the protagonist (or hero), who must leave her/his home, travel into unfamiliar territory, meet a guide, endure dangerous situations and adventures, reach the object of her/his quest, gain important new knowledge, and return home with that knowledge to share with others. The pursuit of solving the mystery crime that happened in the Rue Morgue caught the interest of Dupin and his friend, the narrator.

Since Dupnin was known to be a private person, his primary goal upon hearing the crime was to test his ability. So he left his ignorant self and went out with his friend to try to solve the crime. At first, they went to the crime scene, a building that was rumoured to have women with serious illness. It was their first time to do an investigation in a crime scene. As the story progresses, Dupin and his friend became more curious about who or what had caused the death of the women. Later on, he was able to solve the bizarre crime.

The Fall. The Fall was ultimately labelled on the diminution of the Chief of Police's self-confidence. As a member of a formerly very popular family, Dupin was able to get acquainted with the rich, famous, and well known people even though he does not really like it that much. The Chief of the police was recognized as one of the best in their field. He had solved a lot of crimes and gained the respect of the people within their area. He had much pride in himself until Dupin solved the mystery of the murders in the Rue Morgue.

\section{B. SETTING ARCHETYPE}

\section{Summer}

Summer symbolizes adventure and alliance.

The story was introduced to have happened on a summer night in Paris, France. It represents the adventures of Dupin and his friend towards the unravelling of the mystery on the murders in Rue Morgue. Also, it symbolizes friendship, when, during summer, the narrator met August Dupin in a bookstore and was fond of him. He knew that Dupin is an intelligent man and eager to be his friend.

Summer represents youth.

The murder story represents youthfulness or the childhood of its genre. As the pioneer mystery story, and the first murder story of Edgar Allan-Poe, it brought out a new taste of reality fiction in literature. The short story started quite unpredictable since mystery was its genre.

Night

Night represents darkness, death and mystery. It was a night that the lives of Mrs. L'Espanaye and her daughter ended. It was the moment the orang-utan entered their room. It was dark and cold and the animal has nowhere to hide. As a result, it climbed 


\section{The Murders in the Rue Morgue by Edgar Allan-Poe: A Content Analysis in the Context of Archetypal Approach}

up the pole and entered the room where the women were at since the room during that time was the one emitting light and attracted the attention of the animal. Due to the fright brought by the ugly face of the animal, the women shouted in terror. The animal panicked and made his last resort and killed the women.

\section{Streets}

Streets on cities are often seen as rivers, flowing with the current of life which refers to the people who are walking or strolling along the streets or through vehicles.

In a particular part of the story, as Dupin and his friend were walking in the streets of Paris, his friend was able to realize how brilliant Dupin was. While they were down the dirty and long street, a fruit-seller bumped into Dupin's friend which was a proof that streets are usually busy and full of diverse people. Some try to make a living while some just walk around observing things.

\section{SYMBOLIC ARCHETYPE}

Window

Windows represent gateway and an opportunity. In the story, one of the windows in the room of the victims became the entryway of the murderer, the orang-utan. The beast went inside by the window when it saw the light coming from the room.

\section{Books}

Books mean man's intelligence and ability to communicate. Dupin was introduced as a guarded and private person who was fond of reading rare books. Looking back into the first part of the story, when the narrator starts introducing the main character, it was mentioned that Dupin likes books. They met in a bookstore while they were looking for a particular book, a book that was rarely read, a book of value that only intelligent and patient minds would give time to read. As a member of a well-known family, Dupin had more time spending with reading books than socialize with people around him. He reads and thinks a lot, that even his friend was amazed of how extensively he had read and asked Dupin to live with him for he is sure that Dupin would greatly love his fine books.

Although they had lived together, they do not talk too much. They think about the things they have read and sometimes, share perceptions. Dupin is a person honed by books, for his love for books sharpened his mind.

\section{Four}

Four as an archetype means woman, mankind (four limbs), and square (material stability.

Four, plays a significant symbol in the story, where two women were found dead on the fourth floor of an apartment (building). The figure became vital since it is in the crime scene. Four clearly signifies women who were the focus and victims of the crime. The setting of the murders is connected with the gender of the individuals residing in the room. The apartment building, symbolizing the material of stability, became the sanctuary of the women as they tried to live and survive. They have been living in the apartment for years and did not socialize with people.

\section{Hands}

Hands represent ones absolute manipulation of the world around them.

The absolute manipulation in the story is the strength of the orang-utan. With his hands, he strangled, grappled, threw and killed two fragile women. With his hands, he maneuvered a severe crime, which is the focus of the story.

\section{CHARACTER ARCHETYPE \\ Dupin as the Hero}

The hero is one of the main story characters. He is the mana personality and the defeater of evil dragons. Basically, he represents the ego and is often engaged in fighting the shadow, in the form of dragons and other monsters. The hero is, however, often dumb as a post. He is, after all, ignorant of the ways of the collective unconscious.

The story is about the bizarre murders that happened in Paris. And in Paris, Dupin and his friend lived. August Dupin was rated as the hero of the story for he possesses the mana personality. Not precisely that he had fought with the dragons, but he was able to pin point what was behind the mysterious killings that had helped the police solve the crime even though he was the type of person who does not like to blend with people that much. Dupin was a very private person. He preferred to be alone, with books to feed his mind and soul. Also, he did not like mingling with people. He was selective when it comes to friends and was just very observant. But when the day the crime broke out, Dupin and his friend, whose main agenda was only to try solve the crime and measure their intelligence unintentionally, have given a lot of help to the police.

\section{Orang-Utan as the Beast}

Orang-utan symbolizes the beast which represents the wild

human trope. 


\section{The Murders in the Rue Morgue by Edgar Allan-Poe: A Content Analysis in the Context of Archetypal Approach}

The orang-utan in the story portrayed the archetype of the beast or the wild human trope. Its appearance is somewhat human, yet brutish in nature and more frightening than that of an ordinary human.

While the orang-utan was straying at the streets of Paris, all it wanted is a place to stay and probably play. Given that the animal is from the wild, it is eager to go back to where it came from. But then when a light from a room struck his attention, the animal decided to go up the pole and enter the room and ended up killing the women.

\section{DISCUSSION}

The Archetypal Approach evaluated the hidden symbols and collective consciousness present in the story The Murders in the Rue Morgue and associated it to reality. The researchers compared and synthesized the analyses of the corroborators if there were similarities in their interpretations with that of the researchers. The following were the findings of the study:

\section{A. Situation Archetype}

The Quest is the pursuit of solving the murders of

Mrs.L'Espanaye and her daughter.

The Fall was represented by the ridicule the Chief of the Police had after his disappointment to the fact that none in their league was able to crack the mystery of the gruesome murder.

\section{B. Setting Archetype}

Summer is the symbolism of adventure, youth, and vigour. It represented the enthusiasm of the main character and his friend on the mystery crime.

Night symbolized darkness, death, and mystery. It was in a hot summer night when the murder happened along with the mystery of who or what was the murderer.

Streets were the symbolism of path, fertility, and crowd.

The place where Dupin and his friend lived was near the streets.

Also, the mystery murders happened in the apartment located at Rue Morgue which is one of the famous streets in Paris. It can be considered fertile for it consists of diverse people sharing thoughts, mingling with each other, and earning for a living.

\section{Symbolic Archetype}

Window represented gateway and opportunity. It was the symbol that is connected to the entrance of the orang-utan to the room of the victims. Also, it gave an opportunity to the investigators to successfully solve the heinous crime.

Books symbolized the ability of Dupin to read minds by carefully analyzing facial expressions and gestures. His intelligence and knowledge was very broad like how extensively he has read.

Four had the representations of women, mankind (four limbs), and square (stability). Square signified stability that represents the apartment where the victims live. In addition, the apartment corresponded to the financial stability of the persons residing in that place.

Women who carried the symbol four were the individuals killed by the animal. During the murder, individuals, specifically policemen and neighbors came rushing at the apartment to give help, as what mankind or rational beings should tend to.

\section{Character Archetype}

The orang-utan symbolized the wild human trope. It may look similar to a human but is untamed, undomesticated, and irrational. Its massive size, big long arms, brutish nature, and frightening appearance caused fear to the victims. It embodied the wild and uncontrollable side of men.

Dupin portrayed the hero, being able to solve the mysterious murder in the Rue Morgue.

\section{CONCLUSIONS AND RECOMMENDATIONS}

Based on the findings of the study, it can be concluded that Edgar Allan Poe used different archetypes in his short story The Murders in the Rue Morgue. Furthermore, the archetypes in the story revealed were interpreted using the four Branches of Archetypes such as Situation, Setting, Symbolic, and Character Archetypes. The story has many archetypes that gave a deeper meaning in the story and which depicted realities of life. Also, with these archetypes, important parts of the story were given emphasis and appreciation. The story itself is thrilling but with archetypes, it became way more interesting.

It is therefore recommended that this story will be used as a literary sample in the teaching of literature subjects. Literature teachers could use this analysis as a reference material in their class and that research studies of this kind may be done by future researchers.

\section{REFERENCES}

1) Androski, H. (2001). Golden age of British Detective Novel. Retrieved August 6, 2017 9:05 am from http:// www.twbooks.co.uk/authors/goldenage.html

2) Betita, B. C. (2014). Content Analysis of Jose- Garcia Villa's Footnote to Youth. Unpublished Graduate Research Paper. 
The Murders in the Rue Morgue by Edgar Allan-Poe: A Content Analysis in the Context of Archetypal Approach

3) Northern Iloilo Polytechnic State College, Estancia, Iloilo.

4) Biñas, G. C.(2015). The Symbolisms in the Poetry of Emily Dickinson. Unpublished Graduate Research Paper. Northern Iloilo Polytechnic State College, Estancia, Iloilo.

5) Duriau, R. and Pfarrer M. (2017). What is content analysis? Retrieved July 30, $20173: 17$ pm from https://www.terry.uga.edu/management/contentanalysis/re search/

6) Fleer, B.E. (2014). The Application of Jungian Archetypes to the Character in the Three Early Plays by

7) W.B. Yeats. Retrieved August 8, 2017 9:35 pm from https://mospace.umsystem.edu

8) Henderson, G., Day, W. \& Waller, S. (2006). Literature and Ourselves. Retrieved August 8, 2017 2:12 pm from http://www2.sdfi.edu.cn/netclass/jiaoan/englit/ englit/criticism.htm

9) James, P.D. (2012). Talking and Writing Detective Fiction. Retrieved August 05, 2017 3:09 pm from https://npr.org

10) Lopez, V. (2001). Literary Criticism as a Tool for Interpreting Literature. Retrieved September 12, 2017 8:05 pm from https://www.uv.es

11) Muri, A.(2017). Writing Help: Literary Analysis. Retrieved August 1, 2017 12:34 pm from http://www. headlesschicken.ca/writinghelp/ literary_analysis.html

12) Peters, J. (2017). Psychology of Personality. Retrieved September 23, 2017 6:00 pm from https://www.google.com.ph/myfreshcanvas.com

13) Peterson, T. (2014). Literary Analysis Sample Paper. Retrieved September 23, 8:15 pm from http://www. germanna.edu/documents/literary-analysis-sample- paper.pdf

14) Rexroth, K. (2017). Literature. Retrieved August 3,2017 4:01 pm from https://www. britannica.com/art/literature

15) The Editors OfEncyclopedia Britannica(2014). The Murders in the Rue Morgue. Retrieved August 1, 2017 6:08 pm from https://www.britannica.com/topic/TheMurders-inthe-Rue-Morgue

16) Weidhardt, G. (2017). Writing Detective or Mystery Stories. Retrieved September 14, 2017 7:34 pm From https://www.thebalance.com

17) Wimmer, J. (2015). Short Stories: Definition, Characteristics, \& Examples. Retieved date August 12, 2017 4:50 pm from http://study.com/academy/lesson/ short-stories-definition-characteristics-examples.html 